\title{
Experimental Studies on the Rheological and Hydraulic Performance of Palm Based Hydraulic Fluid
}

\author{
W. B. Wan Nika*, F. Zulkiflia, S. S. Lamª, M. M. Rahmanª, A. A. Yusofb, M. M. Rahmanc \\ ${ }^{a}$ School of Ocean Engineering, Universiti Malaysia Terengganu, 21030 Kuala Terengganu, Terengganu, Malaysia \\ ${ }^{b}$ Faculty of Mechanical Engineering, Universiti Teknikal Malaysia Melaka, 76100 Durian Tunggal, Melaka, Malaysia \\ 'Faculty of Pharmacy, International Islamic University Malaysia (IIUM), 25200 Kuantan, Pahang, Malaysia
}

*Corresponding author: niksani@umt.edu.my

\section{Article history}

Received :9 December 2013

Received in revised form

17 January 2014

Accepted :25 January 2014

\section{Graphical abstract}

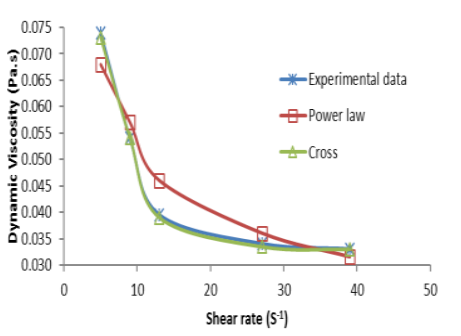

\section{Abstract}

Development of environmental friendly hydraulic fluid has a major influence in ecologically benign environment. The use of plant oil as hydraulic fluid would help to minimize hazardous pollution caused by accidental spillage, lower disposal costs of the used fluid and meet the environmental regulations. Hydraulic test rig was built to conduct endurance test where it can be operated continuously with several safety features. This research was conducted to evaluate the rheology elements and hydraulic performance of palm based hydraulic fluid. The palm oil shows decreasing trend in volumetric efficiency as the pressure increase while the mechanical efficiency increases as the pressure increase. Properties and characteristics of palm based hydraulic fluid were evaluated via rheology study. The effect of viscosity with temperature and shear rate was studied. The influence of shear rate and temperature on the variation of viscosity was clearly observed but temperature has more significant influence. Interpretations of rheological models indicate that this palm based hydraulic fluid belongs to pseudo-plastic category. Further analysis was done to fit the experimental data with two models and the findings show that Cross rheological model fits well with the experiment data. The plant oil was used in 1000 hours operation in a hydraulic system built in Universiti Malaysia Terengganu. The overall results suggest the potential substitution of palm oil as hydraulic fluid in marine applications.

Keywords: Hydraulic fluids; mechanical efficiency; palm oil; rheology; volumetric efficiency

\section{Abstrak}

Pembangunan bendalir hidraulik mesra alam sekitar mempunyai pengaruh yang besar dalam memulihara alam sekitar dan ekologi. Penggunaan minyak tumbuhan sebagai bendalir hidraulik akan membantu mengurangkan pencemaran berbahaya yang disebabkan oleh tumpahan sisa minyak, mengurangkan kos pelupusan dan mematuhi peraturan-peraturan alam sekitar. Alat pengujian hidraulik dibina untuk menjalankan ujian ketahanan di mana ia boleh dikendalikan secara berterusan dengan beberapa ciri-ciri keselamatan. Kajian ini dijalankan untuk menilai unsur-unsur reologi dan prestasi bendalir hidraulik berasaskan sawit. Minyak sawit menunjukkan penurunan dari segi kecekapan isipadu apabila berlaku peningkatan tekanan manakala kecekapan mekanikal bertambah apabila tekanan meningkat. Ciri-ciri bendalir hidraulik berasaskan sawit telah dinilai melalui kajian reologi. Kesan kelikatan dengan suhu dan kadar ricih telah dikaji. Pengaruh kadar ricih dan suhu ke atas perubahan kelikatan adalah jelas dengan suhu mempunyai pengaruh yang lebih signifikan. Interpretasi model reologi menunjukkan bahawa bendalir hidraulik berasaskan sawit ini menunjukkan ciri-ciri pseudo-plastik. Analisis lanjut dilakukan untuk menguji kesuaian data ujikaji dengan dua model dan kajian menunjukkan bahawa model Cross lebih memadani dengan data ujikaji. Minyak tumbuhan ini telah digunakan dalam system hidraulik yang dibina di Universiti Malaysia Terengganu dan ujikaji ini telah dijalankan selama 1000 jam. Keputusan keseluruhan mencadangkan penggantian minyak sawit yang dilihat berpotensi sebagai bendalir hidraulik dalam aplikasi marin.

Kata kunci: Bendalir hidraulik; kecekapan mekanikal; minyak sawit; reologi; kecekapan isipadu

(C) 2014 Penerbit UTM Press. All rights reserved. 


\subsection{INTRODUCTION}

Development of natural based product is one of the alternatives to protect the environment from hazardous materials. Plant oil such as jojoba oil, coconut oil, crambe oil and palm oil has been studied thoroughly because of its environmental friendly characteristic $^{1-3}$. Furthermore, the wide range of application exhibits by these oils had also increase great interest in this field ${ }^{4}$. Numerous researchers have conducted studies on plant oil and found that these plant oils are suitable to be used as biodiesel, alkyd resins, printing inks, lubricants and cosmetics products ${ }^{5}$.

The construction of mega structure including ship, desalination plant and offshore structure symbolized the rapid growth of marine industry. Hence, the demand on lubricant, fuel and hydraulic fluid is also increasing ${ }^{6}$.

The existing lubricants, fuel and hydraulic fluid in the market is mineral based or petroleum based oil in which can bring harm to the environment and ecosystem in the case of leakage or spillage $^{7}$. Legislative and moral concern has caused International Maritime Organization (IMO) to endorse the Annex VI of the MARPOL 73/78 convention which associated in controlling the ship disposal. Plant oils are suitable to be used in marine application because of its high biodegradability (95\% of plant oils is biodegradable). Other attributes are high natural viscosity (30$80 \%$ higher than mineral oils), excellent lubricity due to ester functionality and high flash point ${ }^{8}$. Lubricity study of various plant based oils has been made by various researchers ${ }^{9-13}$. Palm oil methyl ester specifically was investigated by using four ball tribometer ${ }^{14}$.

The flow through hydraulic components especially a pump can be categorized as main flow and the leakage flow. The main flow is extremely complex and it is neither steady nor uniform. This can be due to the motion of vane and non-uniform hydraulic flow path. The volumetric efficiency in this study can be written as in Equation $1^{15}$ :

$$
\eta_{v p}=1-C_{s} \frac{P_{p}}{2 \pi \mu W_{p}}-\frac{Q_{R}}{D_{p} W_{p}}
$$

where: $C_{s}$ is the kinematic viscosity $(\mathrm{cSt}) ; P_{P}$ is the pump pressure (Pa); $\mu$ is the visocity (Pa.s); $W_{p}$ is the viscosity at zeroshear rate $(\mathrm{N} . \mathrm{m} / \mathrm{s}) ; Q_{R}$ is the pump flow rate $\left(\mathrm{m}^{3} / \mathrm{s}\right)$ and $D_{p}$ is the pump diameter $(\mathrm{m})$.

It should be noted that the second term of Eq. 1 is the losses due to leakages and the last term is due to the compressibility effect. Meanwhile, the mechanical efficiency and mechanical losses are due to viscous friction and coulomb friction. The mechanical efficiency is defined as the ideal torque divided by the actual torque as shown in Equation $2^{15}$ :

$$
\eta_{m p}=\frac{D_{p} P_{p}}{T_{a}}
$$

where: $D_{p}$ is the diagram power $(\mathrm{w}) ; P_{P}$ is the pump pressure $(\mathrm{Pa})$ and $T_{a}$ is the actual torque (N.m)

Taking into account all the torque losses, mechanical efficiency can be expressed as Equation $3^{15}$ :

$$
\eta_{m p}=\frac{P_{p}}{\frac{P_{p}}{2 \pi}+C_{c} \frac{P_{p}}{2 \pi}+C_{v} \mu W_{p}}
$$

where: $P_{P}$ is the pump pressure $(\mathrm{Pa}) ; C_{c}$ is the contraction coefficient; $C_{v}$ is the velocity coefficient; $\mu$ is the viscosity (Pa.s) and $W_{p}$ is the oil power.

Viscosity is a direct indication on the stickiness of the fluids under studied. Higher viscosity indicates higher stickiness of the fluids and vice versa. Viscosity is the derivation of the relationship between shear stress and shear rate which can be expressed as Equation (4) ${ }^{16}$.

$$
\eta=\tau / \frac{d u}{d x}
$$

where: $\tau$ is the shear stress $(\mathrm{Pa}) ; d u / d x$ is the shear rate $(1 / \mathrm{s})$; and $\eta$ is the viscosity (or dynamic viscosity) (Pa.s). An increasing of shear stress leads to a greater portion increase in shear rate and hence reducing viscosity value as indicated by viscometer. This phenomena is known as shear thinning behavior while for inverse observation, it exhibits shear-thickening.

Shear thinning behavior can be modeled by two models known as Power Law and Cross. These equations are presented in sequence as in Equation (5)-Equation (6) $)^{17-18}$.

$$
\begin{gathered}
\eta=K_{p} \gamma^{n_{p}-1} \\
\eta=\eta_{\infty, \gamma}+\frac{\eta_{0, \gamma}+\eta_{\infty, \gamma}}{1+\left(\alpha_{c} \gamma\right)^{m}}
\end{gathered}
$$

where: $K_{p}$ is the consistency index $\left(\mathrm{Pa} . \mathrm{s}^{\mathrm{n}}\right) ; \eta_{P}$ is the flow behavior index (dimensionless); $\eta_{\infty, \gamma}$ is the viscosity at infiniteshear rate (Pa.s); $\eta_{o, \gamma}$ is the viscosity at zero-shear rate (Pa.s); $\lambda_{c}$ and $\alpha_{c}$ are the characteristic relaxation time (s); $\eta_{0}$ is the yield stress-viscosity at initial flow condition (Pa.s) and $\eta^{\prime}$ is the Bingham plastic viscosity (Pa.s).

This study was conducted to study the rheological aspects of palm based hydraulic fluid as well as its performances. This present work would help to promote the application of natural resources as well as to protect the environment. For the betterment of mankind, environmental friendly and sustainable source of biohydraulic fluid is to be sought for future use.

\subsection{EXPERIMENTAL}

\subsection{Palm Oil Selection}

Palm oil used in this experiment is provided by a local refinery. The palm oil has some oleic, palmitic, stearic, linoleic and lauric contents. The chemical composition of the oil used is given in Table 1. The most abundant fatty acid in this oil is oleic. More than $40 \%$ of fatty acid is unsaturated. Saturated fatty acid was also found to be more than $40 \%$. 
Table 1 Fatty acid composition of RBD palm and vegetable hydraulic oils used

\begin{tabular}{|c|c|c|c|}
\hline Common name & Systematic name & Symbol & $\begin{array}{l}\text { \% of total weight } \\
\text { (RBD palm oil) }\end{array}$ \\
\hline \multicolumn{4}{|l|}{ Saturated acids } \\
\hline Lauric & n-Dodecanoic & C12:0 & 0.4 \\
\hline Myristic & n-Tetradecanoic & C14:0 & 1.0 \\
\hline Palmitic & n-Hexadecanoic & $\mathrm{C} 16: 0$ & 38.3 \\
\hline Stearic & n-Octadecanoic & C18:0 & 4.0 \\
\hline Arachidic & n-Eicosanoic & $\mathrm{C} 20: 0$ & 0.7 \\
\hline \multicolumn{4}{|c|}{ Mono-unsaturated acids } \\
\hline Palmitoleic & n-Hexadec-9-enoic & $\mathrm{C} 16: 1$ & 0.4 \\
\hline Oleic & n-Octadec-9-enoic & C18:1 & 43.1 \\
\hline Gadoleic & n-Eicos-9-enoic & $\mathrm{C} 20: 1$ & 0.1 \\
\hline \multicolumn{4}{|c|}{ Poly-unsaturated acids } \\
\hline Linoleic & n-Octadec-9, 12-dienoic & $\mathrm{C} 18: 2$ & 11.6 \\
\hline Linolenic & n-Octadec-9, 12, 15-trienoic & $\mathrm{C} 18: 3$ & 0.2 \\
\hline Others & & $\mathrm{C} 20-\mathrm{C} 22$ & - \\
\hline
\end{tabular}

\subsection{Rheology Study}

Viscosity measurement of plant oil was conducted by using Brookfield (Viscometer DV-I+) rotational type viscometer. Before use, the viscometer (accuracy $\pm 1 \%$ full scale range; repeatability, $0.2 \%$ full scale range) was calibrated with $4.7 \mathrm{cP}$ Brookfield silicone viscosity standard. The viscosity of the oils was measured in triplicate at ten different shear rates. SP-18 spindle was operated at different speeds between 3 and $100 \mathrm{rpm}$. A temperature controller (temperature accuracy of $\pm 1 \%$ ) was used to increase the temperature of the oil samples from 40 up to $100^{\circ} \mathrm{C}$, the oil samples were left 15 minutes until steady state heat transfer was achieved.

The viscosity and percentage of torque were manually recorded when the viscosity reading reached apparent equilibrium (appears relatively constant for reasonable time). The viscosities were calculated at ten different shear rates in $\mathrm{mPa}$ for this plant oil and temperature. The shear stress and shear rate were calculated using formulas suggested for non-Newtonian fluid as shown in Equation $(7)^{19}$.

$$
\tau=\frac{M}{2 \pi R_{b}^{2} h}
$$

where $\tau$ is shear stress; $M$ is torque $(\mathrm{Nm}) ; R_{b}$ is radius of SP18 spindle (m) and $h$ is the height of the spindle (m). The shear rate was calculated as shown in Equation $(8)^{15}$ :

$$
\gamma=1.318 \times N
$$

where $N$ is the speed of spindle (rpm).
The experimental data were fitted to two models (Equation (5)Equation (6) by using Mathematica software version 7.

\subsection{Test Rig}

Figure 1 shows the hydraulic test rig built in Universiti Malaysia Terengganu. It consists of hydraulic reservoir, positive displacement pump, hydraulic motor, pressure control valve, three phase electric motor and cooling system. The instrumentations installed in the system are various temperature sensors, pressure sensors, load sensors and a flow meter.

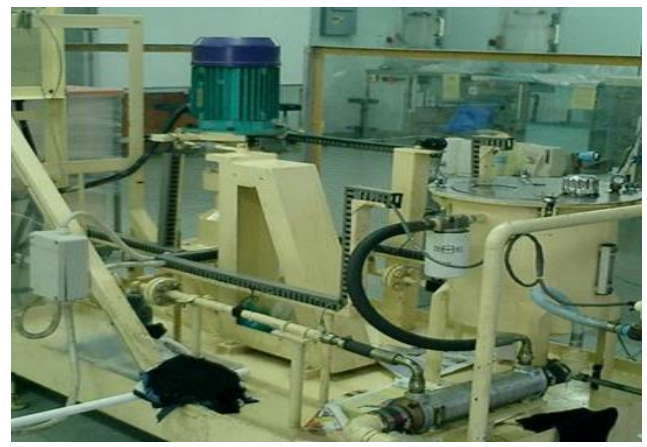

Figure 1 Hydraulic test rig

Figure 2 shows the hydraulic motor which was used as hydraulic actuator. BM3 orbital hydraulic motor with twelve vanes was employed. The hydraulic motor is one type of high torque low speed hydraulic motor, with high efficiency and long life ${ }^{20-21}$. The long life is achieved by employing balanced inlet and 
outlet ports. This type of rotary actuator is used in ship winch applications. It was also chosen since this investigation wants to study the effect non-Newtonian effect of the oil at low speed or at motor's starting speed.

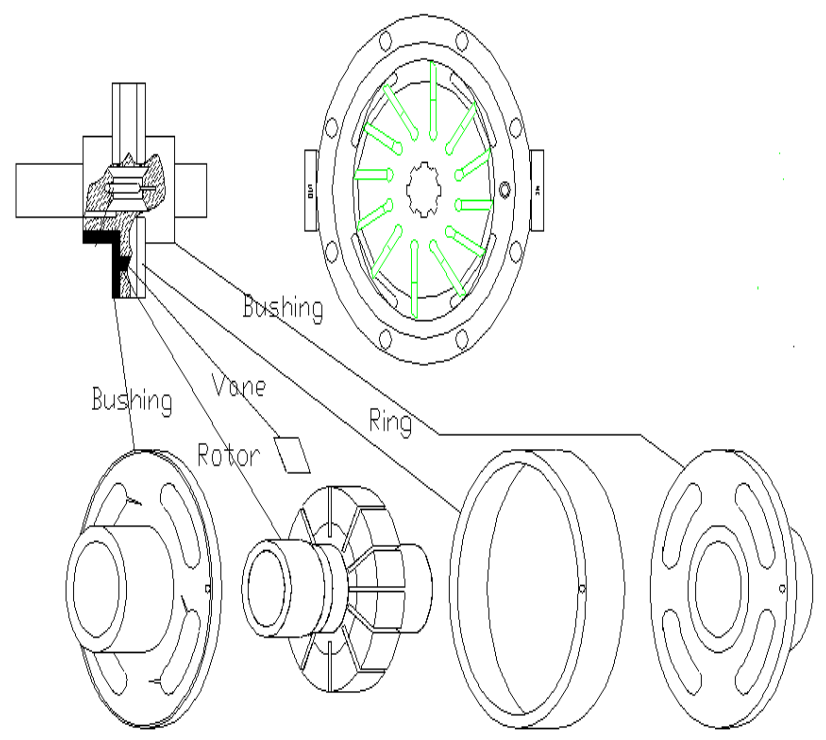

Figure 2 Configuration of the hydraulic motor

The occurrence of sluggish can be noticed when the hydraulic motor is to be started. After passing minimum speed, the motor runs smoothly. Similar observation was made when the motor about to be stopped. Just before stopping, the sluggish motion was observed.

Figure 3 shows the plant oil in the hydraulic reservoir. Initially the colour is reddish. It has clean and clear color. The bubble shown in the picture indicates the foaming characteristics of the oil. The picture also shows the suction filter, thermocouple (to measure inlet oil temperature) and copper coil heat exchanger.

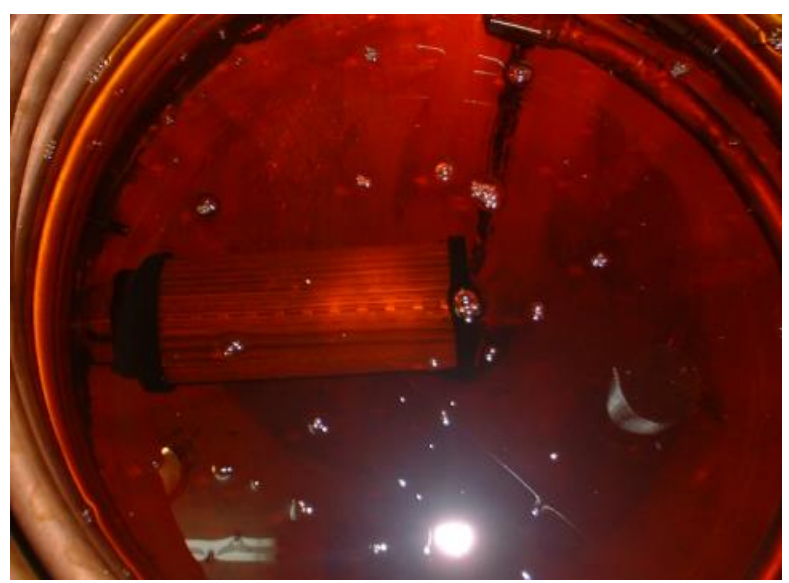

Figure 3 Plant oil in hydraulic reservoir

Figure 4 shows the downstream section of the hydraulic actuator. In this section rotating blades was installed in the oil stream. The rotating speed of the blade has been calibrated to obtain oil flow rate.

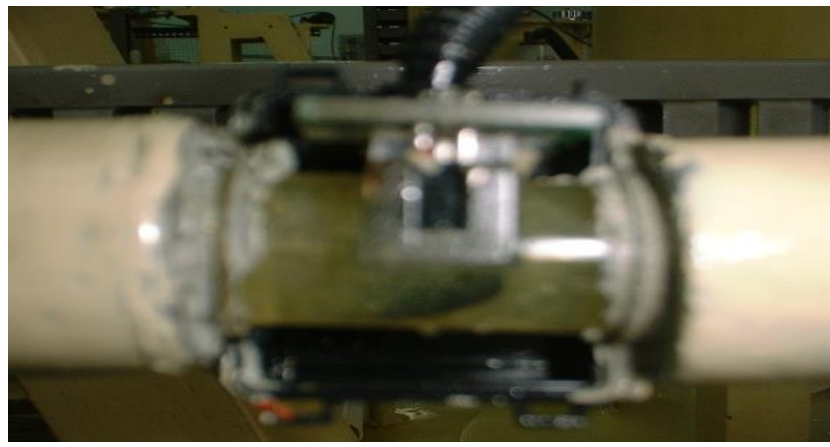

Figure 4 Oil flows through downstream section of hydraulic actuator

\subsection{RESULTS AND DISCUSSION}

\subsection{Rheology Study}

This study is divided into three sections where the first section discusses on the effect of temperature on oil viscosity, the second section discusses the effect of shear rate on oil viscosity and the third section shows the correlation of viscosity, shear rate and temperature.

\subsubsection{Shear Rate Dependence of Oil Viscosity}

Figure 5 shows the viscosity variation for oil samples taken from test rig at 100, 300 and 700 hours. The viscosity increases with operating hours. This is due to oil damage where polymerization occurs and contamination level in the oil increases. Pseudoplastic behaviour is observed for all samples due to decreasing of viscosity with an increasing in the shear rate ${ }^{22}$. The increase in viscosity with reduce shear rate can result in rotating component to stall faster. The high dynamic viscosity at low shear rate means higher torque is required to start the rotating motion. This reduces the mechanical efficiency of the system.

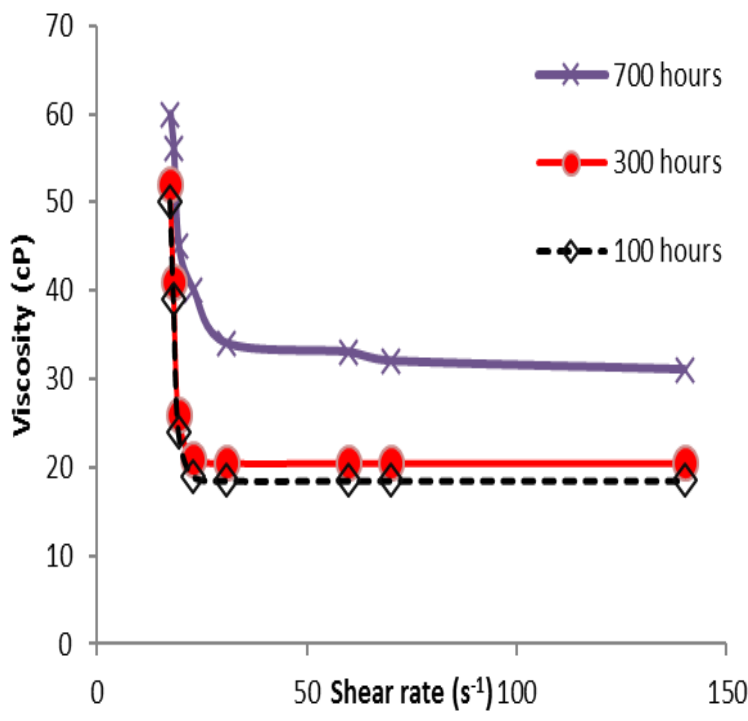

Figure 5 Variation of plant oil with shear rate

To further analyses the data, graph of viscosity versus shear rate is converted to $\log$ viscosity versus $\log$ shear rate form as shown in Figure 6. From this graph, it can be seen that the 
curvature of viscosity versus shear rate can be made close to linear using this log-log format with regression of 0.921 . Details on the fitted data with two rheological models were tabulated in Tables 2 to 5 .

Interpretation of how viscous is the fluid is indicated by $k$. As an example, in Table 2 the values of $k$ decreases with temperature. This indicates that the oil is becoming less viscous at higher temperature. Interpretation of Newtonian can be indicated by $n$. For example, in Table 2, the oil becomes less Newtonian at higher temperature.

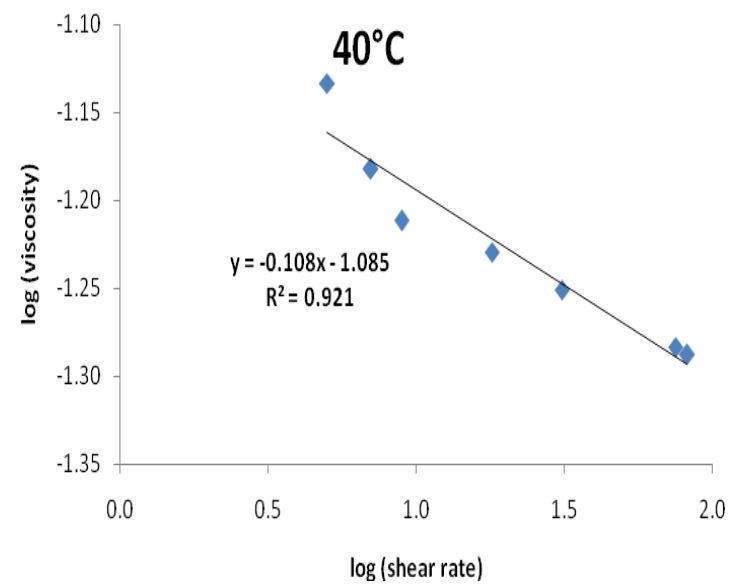

Figure 6 Log viscosity against log shear rate plot

Table 2 Experimental data fitted with Power law model at 700 hours

\begin{tabular}{cccc}
\hline $\begin{array}{c}\text { Temp. } \\
{ }^{\circ} \mathbf{C}\end{array}$ & $\boldsymbol{k}$ & $\boldsymbol{n}$ & $\mathbf{R}^{\mathbf{2}}$ \\
\hline 40 & 0.1238 & 0.7123 & 0.7516 \\
60 & 0.1116 & 0.5413 & 0.9192 \\
80 & 0.1081 & 0.3946 & 0.9649 \\
100 & 0.1021 & 0.3742 & 0.9872 \\
\hline
\end{tabular}

Table 3 Experimental data fitted with Power law model at 300 hours

\begin{tabular}{cccc}
\hline $\begin{array}{c}\text { Temp. } \\
{ }^{\circ} \mathbf{C}\end{array}$ & $\boldsymbol{k}$ & $\boldsymbol{n}$ & $\mathbf{R}^{\mathbf{2}}$ \\
\hline 40 & 0.0625 & 0.8946 & 0.7742 \\
60 & 0.0506 & 0.7783 & 0.8582 \\
80 & 0.0425 & 0.6949 & 0.9475 \\
100 & 0.0386 & 0.6213 & 0.9786 \\
\hline
\end{tabular}

Table 4 Experimental data fitted with Cross model at 700 hours

\begin{tabular}{cccc}
\hline $\begin{array}{c}\text { Temp. } \\
{ }^{\circ} \mathbf{C}\end{array}$ & $\boldsymbol{k}$ & $\boldsymbol{n}$ & $\mathbf{R}^{\mathbf{2}}$ \\
\hline 40 & 1.6840 & 1.4119 & 0.9576 \\
60 & 0.8957 & 1.3735 & 0.9770 \\
80 & 0.2354 & 0.9682 & 0.9873 \\
100 & 0.0809 & 0.8982 & 0.9969 \\
\hline
\end{tabular}

Table 5 Experimental data fitted with Cross model at 300 hours

\begin{tabular}{cccc}
\hline $\begin{array}{c}\text { Temp. } \\
{ }^{\circ} \mathbf{C}\end{array}$ & $\boldsymbol{k}$ & $\boldsymbol{n}$ & $\mathbf{R}^{2}$ \\
\hline 40 & 2.0308 & 1.7441 & 0.9147 \\
60 & 1.2938 & 0.9668 & 0.8968 \\
80 & 0.3377 & 0.9236 & 0.9983 \\
100 & 0.0380 & 0.5937 & 0.9798 \\
\hline
\end{tabular}

Further study was made to investigate the resistance of the oil at low shear rate region. Several rheological models were matched to the experimental data as shown in Figure 7. The test was conducted at room temperature. From the graph, it shows that the Cross rheological model are the best models to represent the hydraulic oil (Equation (5)-Equation (6)). Surprisingly the Power law model does not fit well the experimental data between 10 to $40 \mathrm{~s}^{-1}$ shear rates.

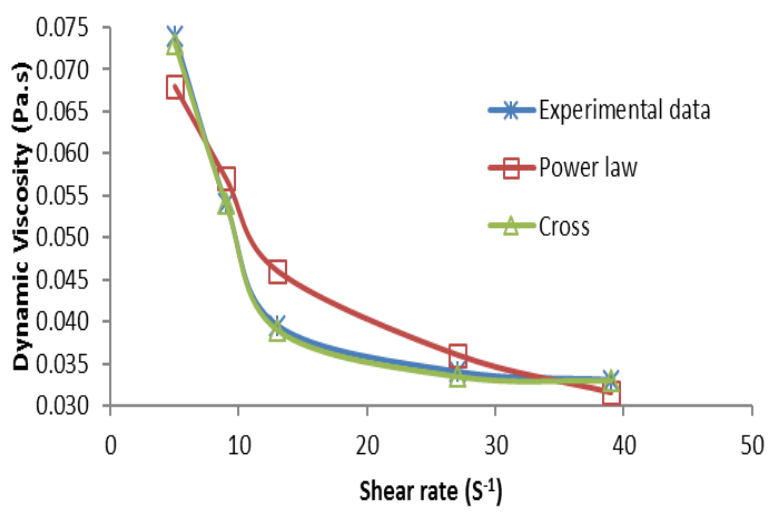

Figure 7 Fitted experimental data with various models

\subsubsection{Correlation of Viscosity, Shear Rate and Temperature}

The viscometric properties of the plant oil are shown in Figure 8 . From a single diagram we can see how the viscosity varies with shear rates at different temperatures. It shows the viscosity decreases as shear rate increases from $3.9 \mathrm{~s}^{-1}$ to $79 \mathrm{~s}^{-1}$, and the viscosity is lowest when tested at $353.15 \mathrm{~K}$. When temperature was lowered to $313.15 \mathrm{~K}$, the viscosity increases respectively. This viscometric pictorial is very important since, in the marine hydraulic system, the oil is subjected to varying shear stress and heat and the variation can occur at the same time. If we can know the stress level and temperature level, then we can straight away find out the viscosity value of the flowing oil. Since both volumetric and mechanical efficiencies are dependent on oil viscosity, then theoretical relationship and actual performance can be evaluated. 


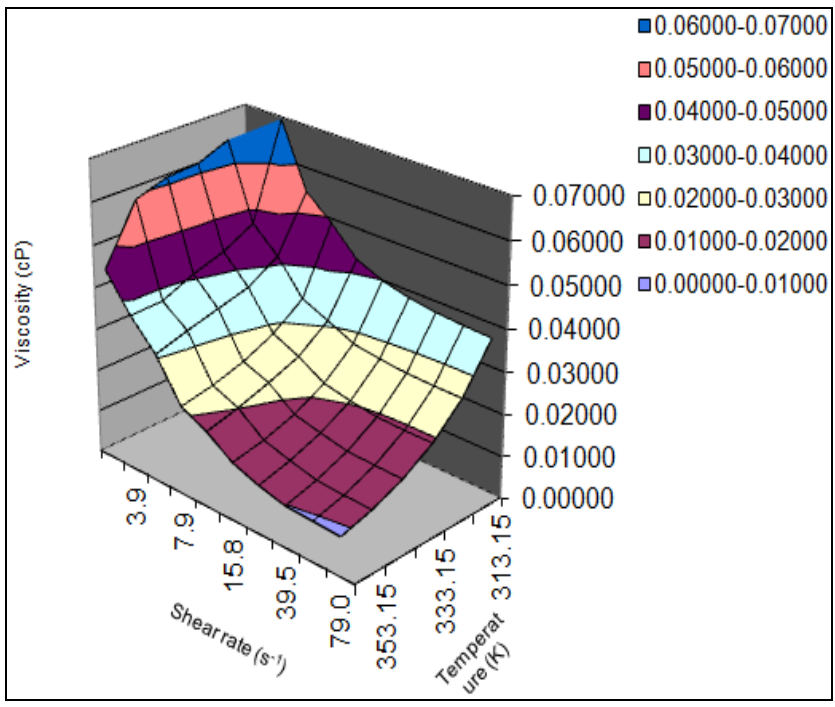

Figure 8 Viscometric properties of plant oil

\subsection{Performance and Modelling Study}

Performance of hydraulic system was evaluated manually. The data was acquired and the mechanical and volumetric performances were calculated manually.

\subsubsection{Comparison of Experimental and Predicted Performance}

Figure 9 shows the result of volumetric efficiency versus pressure. The volumetric efficiency decreases with pressure. The reduction in volumetric efficiency is due to the compressibility effect and leakage. Theoretically oil is compressed about $0.7 \%$ of its original volume for every 100 bar pressure increase. It was observed that there is no external leakage. Thus it can be concluded that the efficiency drop is due to the internal leakage. It is stipulated that the leakage occurs between the vane and cam-ring and between the rotor and side bushing.

Volumetric efficiency is related to the degree of fluid viscosity. Kinematic viscosities for 100, 300 and 700 hours are 44, 52 and 66 centiStokes, respectively. The viscosity increases as the oil has been oxidized from 100 to 700 hours. The increase in viscosity yields in less internal leakage. The less internal leakage give rises to improve volumetric efficiency.

It was observed also that the efficiency reduces not at constant rate with pressure, but decreases at low rate in low pressure region, then at higher rate at higher pressure region. The volumetric efficiency drop in large amount at higher pressure is due to the large pressure difference between the outlet and inlet of the vane pump.

Flow slip coefficient, $C_{s}$, was calculated for each pressure case using Equation 1. Compressibility effect was neglected. Table 6 shows the value for $C_{s}$ for 100 hours case as modelled by Equation 3. The value for $C_{s}$ obtained from the slope of Figure 9 is also shown.

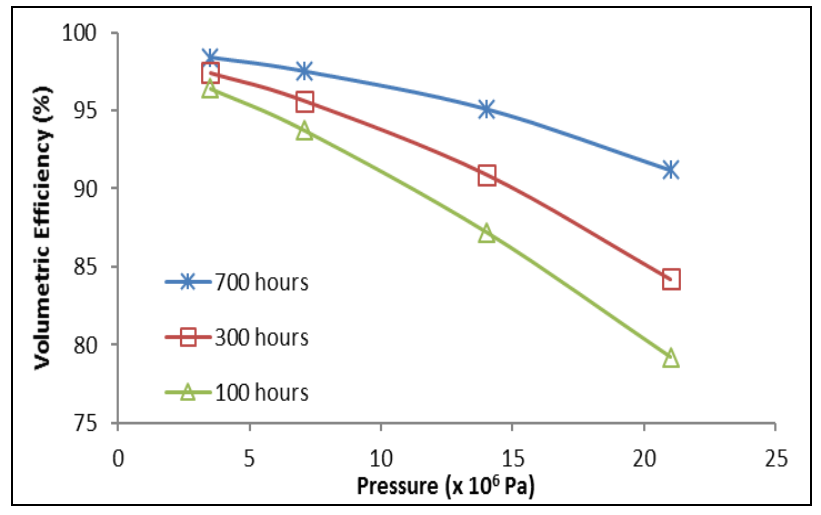

Figure 9 Volumetric efficiency versus pressure

Table 6 Data for 100 hours

\begin{tabular}{cccccc}
\hline $\begin{array}{c}\text { Pressure } \\
(\mathbf{P a})\end{array}$ & $\begin{array}{c}\eta_{\mathrm{v}} \\
\text { Actual }\end{array}$ & $\begin{array}{c}\eta_{\mathrm{v}} \\
\text { Predicted }\end{array}$ & Diff. & $\boldsymbol{C}_{\boldsymbol{s}}(\mathbf{i})^{*}$ & $\begin{array}{c}\boldsymbol{C}_{\boldsymbol{s}} \\
\text { (slope)** }\end{array}$ \\
\hline $3.5 \times 10^{6}$ & 98.4 & 98.4 & 0.0 & $8.45 \times 10^{-9}$ & $3.43 \times 10^{-9}$ \\
$7.0 \times 10^{6}$ & 97.5 & 97.4 & 0.1 & $6.60 \times 10^{-9}$ & $5.52 \times 10^{-9}$ \\
$1.4 \times 10^{7}$ & 95.1 & 93.9 & 1.2 & $6.46 \times 10^{-9}$ & $8.01 \times 10^{-9}$ \\
$2.1 \times 10^{7}$ & 91.2 & 87.6 & 3.6 & $7.74 \times 10^{-9}$ & $1.09 \times 10^{-8}$ \\
\hline & $* C_{s}$ (i) was calculated from Eq. 1 model for each respective pressure. \\
& $* * C_{s}$ (slope) was obtained through the slope measured at each pressure point. \\
$\mu$ @ $70^{\circ} \mathrm{C}=0.012$ Pa.s &
\end{tabular}

The next effort was to model the mechanical efficiency. Equation 3 was used to determine the coulomb $C_{c}$ and viscous $C_{v}$ coefficients. Based on 35 bar and 70 bar cases, it was calculated that the $C_{c}$ and $C_{v}$ were found to be 6.02 and $2.98 \times 10^{5}$, respectively. The model and actual mechanical efficiencies were plotted as in Figure 10. Using the $C_{c}$ and $C_{v}$ of 6.02 and $2.98 \times 10^{5}$, respectively, the predicted mechanical efficiency was calculated for 100 hours, 300 hours and 700 hours cases. The results are tabulated in Table 7.

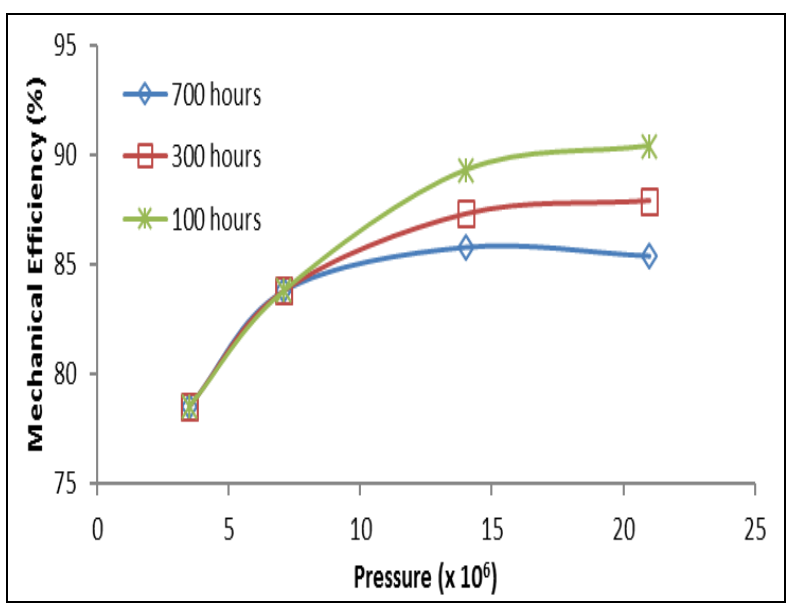

Figure 10 Mechanical efficiency versus pressure 
Table 7 Predicted mechanical efficiency for different speed cases

\begin{tabular}{cccc}
\hline $\begin{array}{c}\text { Pressure } \\
(\mathbf{x ~ 1 0})\end{array}$ & 700 hours & 300 hours & $\mathbf{1 0 0}$ hours \\
\hline 3.5 & 78.5 & 78.5 & 78.5 \\
7.0 & 83.8 & 83.8 & 83.8 \\
14 & 85.8 & 87.3 & 89.3 \\
21 & 85.4 & 87.9 & 90.4 \\
\hline
\end{tabular}

\subsection{CONCLUSION}

Mechanical and volumetric efficiencies show an inverse changes towards each other with respect to pressure. The efficiency also changes with aging property. The investigated palm based hydraulic fluid shows that the temperature has a greater influence on the reduction of viscosity than shear rate. The palm based hydraulic fluid exhibits non-Newtonian behaviour by showing a shear thinning relationship between viscosity (at low temperature) and shear rate which is also known as pseudoplastic behaviour. The shear rate dependence rheological models gave a good fitting on experimental data with $\mathrm{R}$-squared value of 0.921 . The result is promising that the plant oil is suitable to be used as hydraulic fluid in future.

\section{Acknowledgement}

The authors would like to express their deepest gratitude to Ministry of Higher Education for the fund provided (FRGS vot 59210 and ERGS vot 55064) as well as the staff of Maritime Technology Department and Engineering Sciences Department, Universiti Malaysia Terengganu for their help.

\section{References}

[1] W. B. Wan Nik, F. Zulkifli, A. Ahmad, O. Sulaiman, S. Syahrullail. 2011. Hydraulic Field Test Rig and Evaluating Plant Oil Performance. International Journal of Mechanical \& Mechatronics Engineering. 11(5): 19.

[2] A. Adhvaryu, S. Z. Erhan. 2002. Soybean Oil as a Potential Source of High-temperature Lubricants. Industrial Crops and Products. 15(3): 247.
[3] L. Lazzeri, D. M. Franca, B. Fiorenzo, P. Sandro. 1997. Crambe Oil - a Potential New Hydraulic Oil and Quenchant. Industrial Lubrication and Tribology. 49(2): 71.

[4] E. Kassfeldt, D. Dave. 1997. Environmentally Adapted Hydraulic Oils Wear. 207: 41.

[5] W. B. Wan Nik, F. Ani, H. H. Masjuki, E. G. Giap. 2005. Rheology of Bio-edible Oils According to Several Rheological Models and Its Potential as Hydraulic Fluid. Industrial Crops and Products. 22 (3): 249.

[6] G. Mendoza, A. Igartua, B. Fernandez-Diaz, F. Urquiola, S. Vivanco, R. Arguizoniz. 2011. Vegetable Oils as Hydraulic Fluids for Agricultural Applications. Grasas Y Aceites. 62(1): 29.

[7] A. H. Ab Adzis. 2010. On The Usage of Palm Oil as Alternative Non Petroleum-based Hydraulic Fluid in Marine Application. Marine Frontier. 1(2): 62.

[8] Y. Shahidhara, S. Jayaram. 2012. Tribological Studies on AISI 1040 with Raw and Modified Versions of Pongam and Jatropha Vegetable Oils as Lubricants. Advances in Tribology. 2012: 1.

[9] N. W. M. Zulkifli, M. A. Kalam, H. H. Masjuki, M. Shahabuddin, R. Yunus. 2013. Wear Prevention Characteristics of a Palm Oil-Based TMP (Trimethylolpropane) Ester as an Engine Lubricant. Energy. 54: 167.

[10] H. H. Masjuki, M. A. Maleque. 1997. Investigation of The Anti-Wear Characteristics of Palm Oil Methyl Ester Using a Four-Ball Tribometer Test. Wear. 206(1-2): 179.

[11] M. A. Maleque, H. H. Masjuki, A. S. M. A. Haseeb. 2000. Effect of Mechanical Factors on Tribological Properties of Palm Oil Methyl Ester Blended Lubricant. Wear. 239(1): 117.

[12] T. C. Ing, A. K. Mohammed Rafiq, Y. Azli, S. Syahrullail. 2011. The Effect of Temperature on the Tribological Behavior of RBD Palm Stearin. Tribology Transactions. 55(5): 539.

[13] C. I. Tiong, Y. Azli, A. K. M. Rafiq, S. Syahrullail. 2012. Tribological Evaluation of Refined, Bleached and Deodorized Palm Stearin Using Four-Ball Tribotester with Different Normal Loads. Journal of Zhejiang University Science A. 13(8): 633.

[14] S. Syahrullail, B. M. Zubil, C. S. N. Azwadi, M. J. M. Ridzuan. 2011. Experimental Evaluation of Palm Oil as Lubricant in Cold Forward Extrusion Process. International Journal of Mechanical Sciences. 53(7): 549.

[15] Wan Mohd Norsani bin Wan Nik. 2005. Thermal and Rheological Properties of Palm Based Oil as Hydraulic Fluid. Universiti Teknologi Malaysia: Mechanical Engineering Phd Thesis

[16] E. G. Goh, C. S. Kow, W. B. Wan Nik. 2011. Viscometric Performance Evaluation of Oil with Respect to Shear Rate, Temperature and Shearing Time. Jurnal Teknologi. 55: 13.

[17] E. G. Giap, W. B. Wan Nik, M. F. Ahmad, A. Amran. 2009. The Assessment of Rheological Model Reliability in Lubricating Behavior of Vegetable Oils. Engineering e-Transaction. 4(2): 81

[18] M. M. Cross. 1965. Rheology of non-Newtonian Fluids: a New Flow Equation for Pseudoplastic Systems. J Colloid Sci. 20: 417.

[19] N. Mohsenin. 1986. Physical Properties of Plant and Animal Materials. Structure, Physical Characteristics and Mechanical Properties. New York: Gordon and Breach.

[20] L. A. T. Honary. 1996. An Investigation of the Use of Soybean Oil in Hydraulic Systems. Bioresource Technology. 56: 41

[21] L. A. T. Honary. 1998. Making a Case for Soy Based Lubricants. Lubrication Engineering. 54(7): 18

[22] S. M. Al-Zahrani, T. F. Al-Fariss. 1998. A General Model for the Viscosity of Waxy Oils. Chemical Engineering and Processing. 37: 422. 